\title{
HVAC sistemetan koroa-efektuaren agerpena detektatu eta aztertzeko metodologia
}

\author{
(Methodology for the detection and analysis of corona effect \\ in HVAC systems)
}

\begin{abstract}
Ane Miren Larrea, Agurtzane Etxegarai*, Manuel Antonio de la Hoz, Javier Mazón, Elvira Fernández.
\end{abstract}

Ingeniaritza Elektrikoa Saila. Euskal Herriko Unibertsitatea (UPV/EHU)

\begin{abstract}
LABURPENA: Airearen ionizazioa dela eta, tentsio altuko lineetan koroa-efektua sortzen da, eta, ondorioz, elektrizitate-galerak eta lineetan kalteak gertatzen dira. Hortaz, artikulu honen helburua koroa-efektua eta haren detekzioa aztertzea da korronte alternoko goi-tentsioko sistemetan. Ikerketa-metodologiak Jorgensen eta Pedersen-ek lortutako datu esperimentalak erabili ditu, eta kalkuluak Townsend-en teorian oinarrituta daude. COMSOL multiphysics softwarea erabili da eremu elektrikoaren kalkulurako, beharrezko parametroa baita koroa-efektuaren kalkuluan. Lortutako emaitzak MATLAB bidez aztertu dira. Behin metodologia egiaztatuta, presioa, tenperatura, geometria eta simulazio-inguruneak koroa-efektuan duten eragina aztertu dira.
\end{abstract}

HITZ GAKOAK: koroa-efektua, ionizazioa, eremu elektrikoa, dentsitate erlatiboa, elementu finituak.

ABSTRACT: As a consequence of the ionization of the air, corona effect is formed in high voltage overhead lines, resulting into electrical losses and damage. The objective of this paper is to study the corona effect and its detection in high voltage AC systems. The corona detection methodology presented in this paper uses the experimental data obtained by Jorgensen and Pedersen, which are based on the theory of Townsend. COMSOL multiphysics software has been used to calculate the electric field, since it is an essential parameter in the calculation of corona effect. The results obtained have been examined with MATLAB. Once the methodology has been verified, the influence of temperature, pressure, geometry and simulation conditions on corona effect have been analysed.

KEYWORDS: corona effect, ionization, electric field, relative density, finite elements.

\footnotetext{
* Harremanetan jartzeko / Corresponding author: Agurtzane Etxegarai, Ingeniaritza Elektrikoa saila, UPV/EHU, Bilboko Ingeniaritza Eskola, Ing. Torres Quevedo Plaza 1 (48013 Bilbao). - agurtzane.etxegarai@ehu.eus - https://orcid.org/0000-00031933-8485.

Nola aipatu / How to cite: Larrea, Ane Miren; Etxegarai, Agurtzane; de la Hoz, Manuel Antonio; Mazón, Javier; Fernández, Elvira (2019). «HVAC sistemetan koroa-efektuaren agerpena detektatu eta aztertzeko metodologia»; Ekaia, 36, 2019, 127-150. (https://doi.org/10.1387/ekaia.20867).

Jasoa: 16 maiatza, 2019; Onartua: 10 ekaina, 2019

ISSN 0214-9001 - eISSN 2444-3255 / ㄷ 2019 UPV/EHU

(c) (i) (-) Obra hau Creative Commons Atribución 4.0 Internacional-en 
Ane Miren Larrea, Agurtzane Etxegarai, Manuel Antonio de la Hoz, Javier Mazón, Elvira Fernández.

\section{SARRERA}

Aireko lineetako eroaleen gainazaleko tentsioa altua denean, inguruko airea ionizatu egiten da eremu elektrikoaren gradiente handiaren ondorioz. Hortaz, ihes-korronte bat agertzen da eta eroaletik doazen elektroi batzuek airerantz ihes egiten dute, eta aireko molekulak eroale bihurtzen. Eremu uniformeetan, deskarga arku elektriko modura gertatzen da, eta ez-uniformeetan, aldiz, koroa-efektua deritzogu fenomeno horri. Tentsio altuko aireko lineetan gertatzen da. Material bat ez-eroale izatetik eroale izatera pasatzeko, ordea, haustura-tentsioa delakoa gainditu behar da. Hala, airea (edo eroalea inguratzen duen gasa) isolatzaile izatetik eroale izatera pasatzen da. Horretarako, eremu elektrikoaren gradiente erradialak airearen zurruntasun dielektrikoaren balio berdina edo handiagoa izatea lortu behar da. Haustura-tentsioa bakarra da arku elektrikorako eta koroa-efekturako.

Koroa-efektua zaratatsua da eta eroalearen inguruan gertatzen da. Orokorrean aireko lineetako eroaleen geometria zirkularra denez, fenomenoak aureola itxuraren antza hartzen du eta, horregatik, koroa-efektua deritzo. Ikusmen aldetik, koroa efektua jarraitua edo adarkatua izan daiteke, tximista baten antzekoa. Itxura hori hainbat faktoreren mende dago, hala nola [1] polaritatea, aplikatutako tentsioa, elementuen arteko distantzia, etab. Hala ere, kasu guztietan aintzat hartzen da karga elektrikoak kontrako polaritateko kargetara bide eroale batetik doazela.

Koroa-efektuaren ondorio garrantzitsu bat isolatzaileen degradazioa da. Hala, ozonoa $\left(\mathrm{O}_{3}\right)$ eta nitrogeno monoxidoa (NO) agertzen dira, eta inguruko hezetasunarekin erreakzionatuz, azido nitrikoa $\left(\mathrm{HNO}_{3}\right)$ eta nitrogeno dioxidoa $\left(\mathrm{NO}_{2}\right)$ sortzen dira [2]. Fenomenoa kontrolik gabe eta berez sortzen denean, sortutako gasak arriskutsuak bihurtzen dira, nahiko korrosiboak direlako. Gainera, hainbat galera sor daitezke: potentzia galtzen da eta, ondorioz, linearen efizientzia murrizten [3]. Beraz, koroa-efektuaren ezagutza eta ikerketa beharrezkoak dira tentsio altuko gailuak diseinatzean. Gasen jokaera dielektrikoa, ordea, konplexua da eta hainbat ikuspuntutatik azter daiteke: fisika estatistikoa, garraio-fenomenoak, kimika eta elektrostatika, esaterako. Hortaz, gailuen diseinua eta laborategiko neurketak oso zehatzak eta errepikakorrak izan behar dira. Prozesua optimizatze aldera, gaur egun simulazio-ereduak erabiltzen dira.

Honako artikulu honetan goi-tentsioko korronte alternoko (ingelesez High Voltage Alternating Current HVAC) lineetan sortzen den koroa-efektua, hain zuzen ere, aztertuko da elementu finituen simulazio-tresna baten bidez. Izan ere, koroa-efektua maila mikroskopikoan eta makroskopikoan aztertuko da lan honetan, eta, literaturan oinarrituta, haren detekziorako metodologia bat proposatuko da. Metodologia hori egiaztatu ondoren, zenbait faktorek (hala nola ingurune-baldintzak, geometriak eta simulazio-inguruneak) koroa-efektuan duten eragina ikertuko da. 
Lana 5 ataletan banatuta dago. Sarreran, koroa-efektuaren jatorria, ezaugarriak eta ondorioak deskribatuko dira; 2. atalean, koroa-efektuaren oinarri teorikoak azalduko dira, maila mikroskopikoa kontuan izanik; ondoren, 3. atalean, koroa-efektuaren agerpena detektatzeko metodologia bat proposatuko da, elementu finituen bitartez erreferentziako datuekin egiaztatuz. Metodologia baieztatu ondoren, 4. atalean, ikertuko da zer eragin duten koroa-efektuan zenbait faktorek, hala nola ingurune-baldintzak (tenperatura eta presioa), elektrodoen geometriak eta, azkenik, simulazioinguruneak. Lan honen ondorioak 5. atalean laburbilduko dira.

\section{KOROA-EFEKTUAREN AZTERKETA TEORIKOA}

\subsection{Haustura-mekanismoak}

Koroa-efektuaren azterketa teorikoa gasen ahalmen dielektrikoen haustura-mekanismoetan oinarritzen da. Bi ikuspuntu nagusi proposatu dira azterketa horretarako, bi plaka paraleloren ikasketan oinarrituak.

Alde batetik, J. S. Towsend-en arabera, [4] elektroien mugimendua mailakatua eta barreiatua da, elektroi-oldeak sortuz. Olde horiek tanta baten itxura geometrikoa dute; aurreko aldea elektroi arinez osatuta dago, eta atzeko aldea, aldiz, karga positibodun ioi astunagoz. Fenomenoa plaka paraleloetan aztertzen bada, oldeek plaken arteko espazioa zeharkatzen dutenean, karga positibo eta negatiboen bide bat sortzen da. Hala, ondorengo oldeak ere plaken arteko tartea zeharkatzeko gai izango dira, baina lehenengo oldeak baino bolumen handiagoan. Prozesu horretan, kargek sortutako eremu elektrostatikoa mespretxa daiteke, plaketan aplikatutako eremuaren aldean.

Beste alde batetik, Meek eta Loeb-ek proposatutako mekanismoa [5] itxura irregularreko bide eroale batean oinarritzen da, serpentina edo ingelesez streamer deiturikoan. Kasu horretan, haustura-prozesua karga-andana bakar baten mugimenduarekin hasten da. Horrela, bi plaken artean kargadun partikulen bide bat sortu ostean, anodotik katodora zuzentzen dira kargak. Ondorengo oldeek partikula positiboetara jotzen dute, eta haustura-distantzia gutxitzen. Gainera, partikula positiboak dielektrikoan daudenez, aplikatutako eremu elektrikoa baino handiagoa den eremu bat sortzen da. Karga positiboak elektrodoen arteko distantzia zeharkatzeko gai badira, arku elektrikoa sortzen da; bestela, koroa-efektua.

\subsection{Koroa-efektua eta haustura-irizpideak}

Koroa-efektua aztertu zuen lehenengoko ikertzailea Peek iparramerikarra izan zen, XX. mendearen hasieran. Hain zuzen ere, formula esperimental batzuk lortu zituen haustura-tentsioa kalkulatzeko [6], (1) ekuazioan ager- 
Ane Miren Larrea, Agurtzane Etxegarai, Manuel Antonio de la Hoz, Javier Mazón, Elvira Fernández.

tzen den moduan. Haustura-tentsioak geometria eta baldintza klimatologikoak hartzen ditu kontuan zuzenketa-koefiziente batzuen bidez; hurrenez hurren, $\mathrm{m}_{\mathrm{c}}$ zimurtasun-koefizientea eta $\mathrm{m}_{\mathrm{t}}$ koefiziente meteorologikoa.

$$
V_{c}=\frac{29,8}{\sqrt{2}} \cdot \sqrt{3} \cdot m_{c} \cdot \delta \cdot m_{t} \cdot r \cdot \ln \left(\frac{G M D}{r}\right)
$$

non $\delta$ dentsitate erlatiboa den; $r$, eroalearen erradioa, cm-tan, eta GMD, distantzien batezbesteko geometrikoa, cm-tan .

Haustura-tentsioa kalkulatzeko Peek-en ekuazioak eremu-tarte zehatz batzuetan soilik balio du eta, gainera, datuak interpolatzeak errore handiak sor ditzake [7]. Arazo horren soluzio bat formula erdienpirikoak erabiltzea izango litzateke. Jorgensen eta Pedersen-ek, Townsend-en teoria klasikoan oinarrituz, formula erdienpiriko batzuk lortu zituzten, eta aurretik azaldutako arazoak baztertu [7].

Izan ere, eroalea inguratzen duen gasaren molekula neutro baten ionizazioa eremu elektriko batek azeleratutako elektroi baten talkagatik gertatzen da. Ionizatu diren ioiak zenbatesteko, $\boldsymbol{\alpha}\left[\mathrm{cm}^{-1}\right]$ ionizazio-koefizientea definitu zuen Townsend-ek [4], arestian azaldutako haustura-mekanismoan oinarrituta.

$$
\frac{d n}{d s}=\alpha \cdot n
$$

non $n$ elektroi kopurua den, eta s, elektroiaren eta iturriaren arteko distantzia.

(2) ekuazioa erabil daiteke baldin eta elektroi-olde bakarra gertatzen bada. Baina elektroi-oldea oso luzea denean, $\alpha$ ez da berdina tarte guztietan. Beraz, Townsend-en ekuazioa ez da baliagarria. Ver Planck zientzialariak, Townsend, Wheatley, Paavola, Masch eta Sanders-ek lortu zituzten datu esperimentaletan oinarrituta [8], ionizazio-koefizientea esperimentalki azaldu zuen eremu elektrikoa tarteka banatuz. $\alpha$-ren eta eremuaren arteko erlazioa gasaren $\delta$ dentsitate erlatiboaren mende aztertu zuen, 1. irudian ikusten den bezala. Dentsitate erlatiboa (3) koefiziente zuzentzaile bat da, eta presioa eta tenperatura kontuan izaten ditu airearen dentsitatea zuzentzeko.

$$
\delta=\frac{p_{0}}{p} \cdot \frac{T+273}{T_{0}+273}=\frac{1}{p} \cdot \frac{T+273}{293} \quad\left(p(\operatorname{atm}) \text { eta } T\left({ }^{\circ} \mathrm{C}\right)\right)
$$

non $p_{0}$ eta $T$, hurrenez hurren, baldintza normaletako presioa eta tenperatura diren, eta $p$ eta $T$, baldintza berrietako presioa eta tenperatura. 


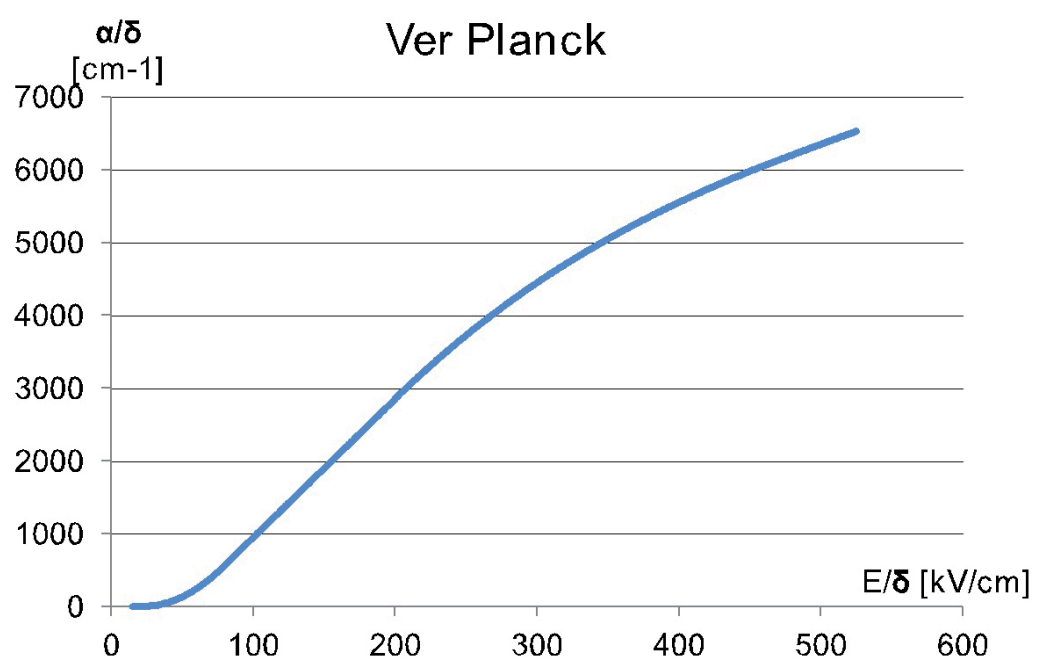

1. irudia. Eremu elektrikoaren eta ionizazio-koefizientearen arteko erlazioa.

Haustura-puntua kalkulatzeko, Meek-ek $g(x)$ funtzioa proposatu zuen, (4) ekuazioan agertzen den moduan.

$$
\ln \left(\alpha_{x}\right)+\int_{0}^{x} \alpha \cdot d x=g(x)
$$

non $\alpha_{x}$ baita elektroi-oldearen burua eta lerro kritikoaren hasiera-puntuko distantzia.

Izan ere, Towsend-en haustura-mekanismoaren arabera, elektroi-oldeak tanta baten itxura hartzen du, eta haren buruaren kokapena aplikatutako tentsioaren polaritatearen arabera aldatzen da [7]. Polaritatea positiboa denean, elektroi-oldearen burua kargatutako gunetik urrun egongo da. Negatiboa denean, aldiz, lerro kritikoaren hasierako puntua tantaren burua izango da, eta $\alpha_{x}$ jatorria da (2. irudia).
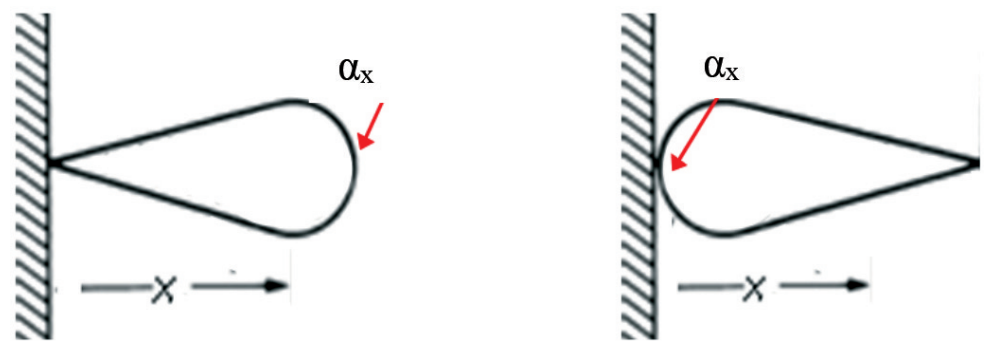

2. irudia. Elektroi-oldearen forma, polaritatearen araberakoa [9]. 
Ane Miren Larrea, Agurtzane Etxegarai, Manuel Antonio de la Hoz, Javier Mazón, Elvira Fernández.

Elektroi-oldeak lerro kritikoaren ibilbideari jarraitzen dio. Pieza baten eremu elektrikoko puntu maximotik hasita masa baztergarriko elektroi batek egiten duen ibilbidea da lerro kritikoa (3. irudia). Eremu elektrikoaren eraginez, elektroia azeleratzen da, eta ibilbide bat marraztuz mugitzen da; ibilbide horri lerro kritikoa deritzo.

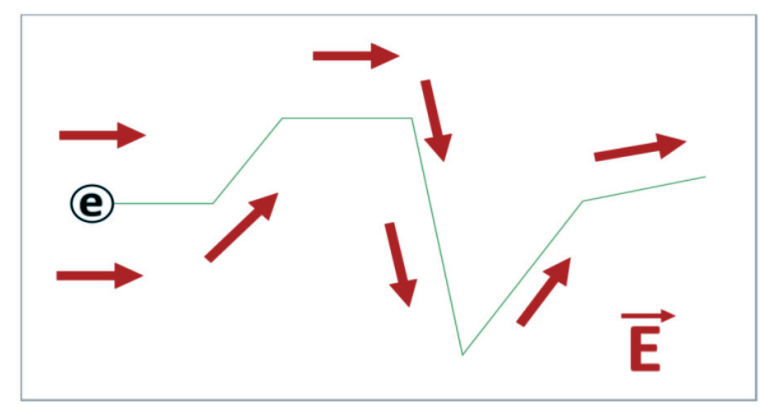

3. irudia. Lerro kritikoa.

Eremu ez-uniformeetan ionizazio-koefizientearen integrala kalkulatu behar da distantziarekiko. Aldiz, eremu uniformeetan konstante mantentzen da ionizazio-koefizientea. Eremu ez-uniformearen eta uniformearen $g(x)$ funtzioek punturen batean elkar ukitzen badute, aplikatutako tentsioan koroa-efektua agertuko da.

$$
\begin{gathered}
\ln \left(\alpha_{x \text { ez-uniformea }}\right)+\int_{0}^{x} \alpha_{\text {ez-uniformea }} \cdot d x=\ln \left(\alpha_{x \text { uniformea }}\right)+\alpha_{\text {uniformea }} \cdot x \\
g(x)_{\text {ez-uniformea }}=g(x)_{\text {uniformea }}
\end{gathered}
$$

Eremu ez-uniformearen $g(x)$ funtzioa kalkulatzeko, Ver Plack-en datu esperimentalak erabil daitezke [8]. Baina, eremu uniformearen $g(x)$ funtzioa kalkulatzeko, hainbat proposamen daude, haustura-tentsioan eta $\alpha$-n oinarrituak. Kontaratos-ek $\alpha$ kalkulatzeko eta haustura-tentsioa kalkulatzeko ekuazioak proposatu zituen [10]. $g(x)$ uniformea kalkulatzeko Cigré erakundearen txostena haustura-tentsioan oinarritu zen [11]. Lortu ziren datuak oso zehatzak ziren, esperimentalak baitziren, baina ez zen ekuaziorik lortu [12]. Paschen-ek, ostera, formula enpiriko bat proposatu zuen haustura-tentsioa kalkulatzeko. Hala ere, $20{ }^{\circ} \mathrm{C}$-ko tenperaturapean erabil daiteke bakarrik. Proposatutako ekuazioa (7) presioan eta iturritik dagoen distantzian oinarritzen da. Emaitza horiek baliagarritzat hartu ziren, segurtasun aldetik onuragarriak direlako [9].

$$
V_{b}=6,72 \cdot \sqrt{P \cdot d}+24,4 \cdot P \cdot d
$$


non $V_{b}$ haustura-tentsioa den, $\mathrm{kV}$-etan; $P$, presioa, bar-etan, eta $d$, distantzia, cm-tan.

\subsection{Koroa-efektuaren detekzioa}

Koroa-efektuaren detektatzeko hainbat aukera daude. Aireko lineetan frogatuta dago koroa-efektuaren agerpena eroaleen erradioaren mendekoa dela [13]. Beraz, (8) baliatuz, ionizazioa agertzeko beharrezkoa den eremu elektrikoaren gradientea kalkula daiteke.

$$
g_{0}=30 \cdot(1-0,7 \cdot r)
$$

non $g_{0}$ eremu elektrikoaren gradientea $(\mathrm{kV} / \mathrm{cm})$ den, eta $r$, eroalearen erradioa, cm-tan.

Baina (8) ekuazioa $25{ }^{\circ} \mathrm{C}$-tan eta presio atmosferikoan da soilik baliagarria. Gainera, ez da edozein geometriatarako aplikagarria; sekzio zirkularra eta uniformea daukaten eroaleetan bakarrik.

Koroa-efektua hautemateko beste metodo bat haustura-tentsioa Peek-en ekuazioaz kalkulatzean eta tentsio maximoarekin aldaratzean datza (tentsio izendatua 1,15 aldiz). Linearen tentsio maximoa haustura-tentsioa baino handiagoa bada, koroa-efektua agertuko da [2].

Hurrengo aukera, aldiz, Meek-ek azaldutako eremu elektriko uniformearen eta ez-uniformearen $g(x)$ funtzioak konparatzea da [7]. Bi funtzio horiek berdinak direnean, koroa-efektua agertuko da. Metodo hori erabiltzeko, ordea, eremu elektrikoa kalkulatzea beharrezkoa da. Espazioko zati batean karga puntual bakarra baldin badago, eremu elektrikoa oso erraz kalkula daiteke. Baina errealitatean karga asko daude, eta eremu elektrikoaren kalkulua zailtzen da. Arazo honi aurre egiteko, badira metodo batzuk.

Alde batetik, zilindro itxurako eroale batentzat, (9) ekuazioa erabil daiteke [2].

$$
E=-\frac{\mu_{0} \omega J_{0} \operatorname{sen}(\omega t) a^{2}}{4}\left(1+2 \operatorname{Ln}\left(\frac{\rho}{a}\right)\right)
$$

non $J_{0}$ maiztasuna $\left(\mathrm{A} / \mathrm{m}^{2}\right)$ den; $\omega$, maiztasunaren abiadura $(\mathrm{rad} / \mathrm{s}) ; t$, denbora $(s)$; $a$, erradioa $(m)$, eta $\mu_{0}$, hutsaren iragazkortasuna $\left(4 \pi 10^{-7} \mathrm{~N} / \mathrm{A}^{2}\right)$.

Beste alde batetik, elementu finituen metodoa (EFM) erabil daiteke eremu elektrikoaren kalkulurako, soilik geometrian eta tentsioan oinarrituz. 
Ane Miren Larrea, Agurtzane Etxegarai, Manuel Antonio de la Hoz, Javier Mazón, Elvira Fernández.

\section{KOROA-EFEKTUA DETEKTATZEKO METODOLOGIAREN EGIAZTAPENA}

Segidan, koroa-efektuaren agerpena aztertzeko metodologia deskribatu, eta lan honetan lortutako emaitzak azalduko dira. Froga bi esferaren artean (esfera-esfera geometria) egingo da, geometria honetan Jorgensen eta Pedersen-ek [7] lortu zituzten emaitzekin konparatu ahal izateko. Horrela, metodologia egiaztatuta geratuko da. Metodologiaren funtsa autore nagusiaren aurreko lan batean oinarritzen da [14].

\subsection{Metodologiaren deskribapena}

Koroa-efektua hautemateko azaldu diren metodoen artean, Meek-ek $g(x)$ funtzioen konparaketarako proposatu zuen metodoa erabili da lan honetan. $g(x)$ funtzioen kalkuluetarako beharrezkoa den $\alpha$ ionizazio-koefizientea Ver Planck-ek proposatutako ekuazioaren bitartez kalkulatu da. Bestalde, eremu elektriko uniformeko $g(x)$ funtzioa kalkulatzeko, Paschen-en proposamena erabili da. Izan ere, Cigré erakundearen datuek, esperimentalak direnez, ez diote inolako ekuaziori jarraitzen eta ez dute ingurumeneko baldintzen aldaketa ahalbidetzen. Gainera, Paschen-en formularekin lortutako emaitzak murriztaileagoak dira. Ondoren, eremu elektrikoa kalkulatzeko, EFM erabili da, COMSOL multiphysics, hain zuzen ere. Metodologia 4. irudian laburbiltzen da, eta ondorengo azpiataletan urratsez urrats azaltzen da.

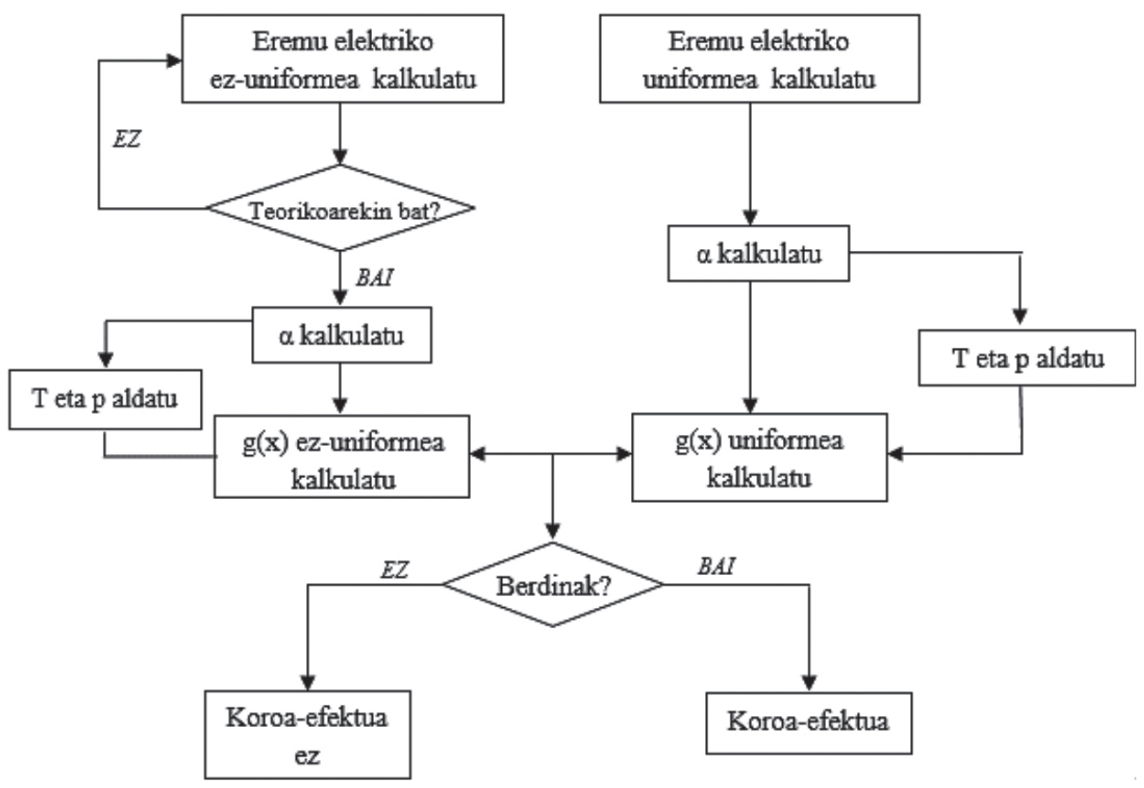

4. irudia. Metodologia azaltzen duen diagrama. 


\subsubsection{Eremu elektrikoaren kalkulua}

Eremu elektriko ez-uniformea kalkulatzeko, COMSOL multiphysics softwarea erabili da. Hasierako pausoa geometria definitzea da (5. irudia). Geometria $25 \mathrm{~cm}$-ko bi esfera izango dira, elkarrengandik $5 \mathrm{~cm}$-ko distantziara bananduak. Ingurunea simulatzeko, 3 m-ko kubo bat eraiki da.
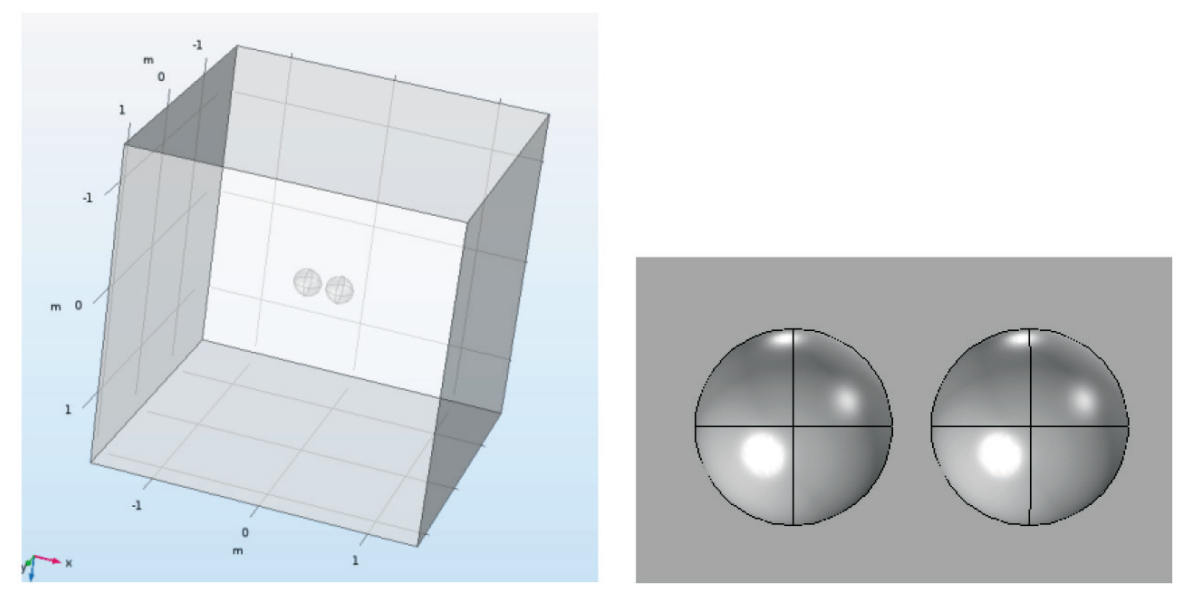

5. irudia. $25 \mathrm{~cm}$ diametroko bi esfera, elkarrengandik $5 \mathrm{~cm}$ aldenduak eta $3 \mathrm{~m}$-ko aldeak dituen ingurune kubiko baten barruan.

Behin geometria sortuta eta materiala definituta egonik, baldintza elektrikoak ezarri dira. Esfera bat $136 \mathrm{kV}$-eko tentsiora konektatu da, eta bestea, aldiz, tentsio nulura. Ingurunea adierazten duen kuboa ere lurrera konektatuta dago.

Eremua kalkulatzeko, geometria saretzea ezinbesteko pausoa da. Geometria guztia sare normal batez saretuko da. Lerro kritikoa pasatzen den inguruneko sarea oso fina izatea garrantzitsua da, emaitzak zehatzagoak izan daitezen. Behin sare nagusia zehaztuta, COMSOL multiphysics-ek kalkuluak egingo ditu ikasketa egonkor batean. Softwareak kalkuluak egindakoan, piezan dagoen eremu elektriko maximoko puntua bilatu behar da. Teorikoki, puntu hori kargatuta dagoen esferan dago, karga nulua daukan esferatik gertuen dagoen puntuan. Kalkulatutako puntuak teorikoarekin bat egiten badu, geometria ondo saretuta dagoelako seinalea da. Horretarako, eremuaren gradientea aztertu behar da. Kurbak dauden gune guztietan eremu elektrikoa gradualki aldatuz, ezin da bat-bateko aldaketarik izan (6. irudia). Puntu maximoa puntu teorikotik urrun baldin badago, edo eremu elektrikoa kurbetan zehar gradualki aldatzen ez bada, geometria finago saretu beharko da. 
Ane Miren Larrea, Agurtzane Etxegarai, Manuel Antonio de la Hoz, Javier Mazón, Elvira Fernández.
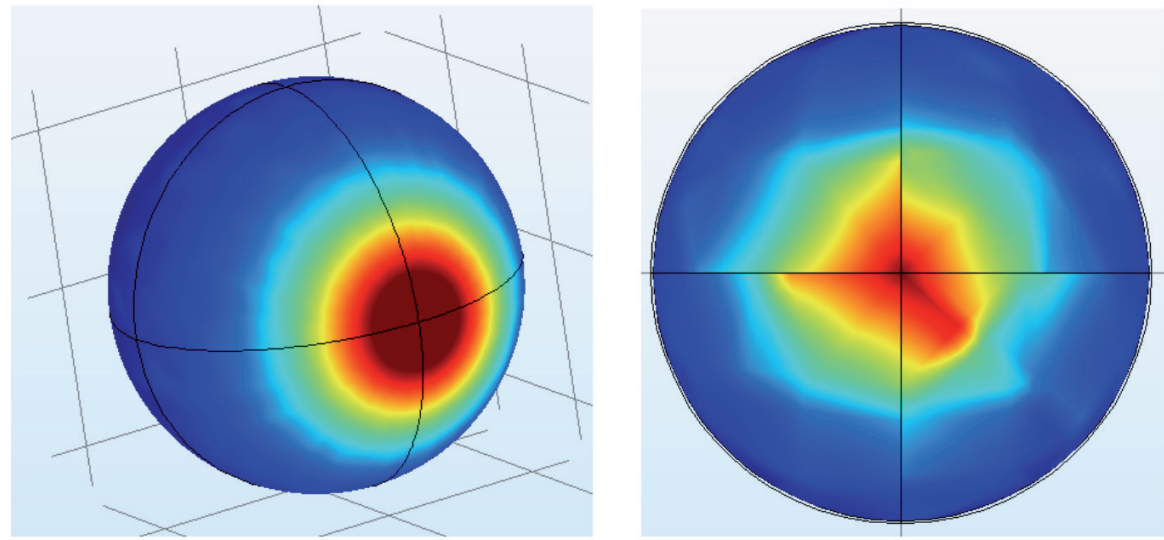

6. irudia. Ezkerrean, eremu elektrikoa gradualki aldatuz. Eskuinean, eremu elektrikoa txarto saretuta.

Koroa-efektua gertatuz gero, elektroi-oldea eremu elektrikoaren puntu maximotik hasiko da. Beraz, eremu elektrikoaren puntu maximoak lerro kritikoaren jatorria zehaztuko du. Lerro kritikoaren eremu elektrikoa jakitea ezinbestekoa da gero $g(x)$ funtzioa kalkulatu ahal izateko.
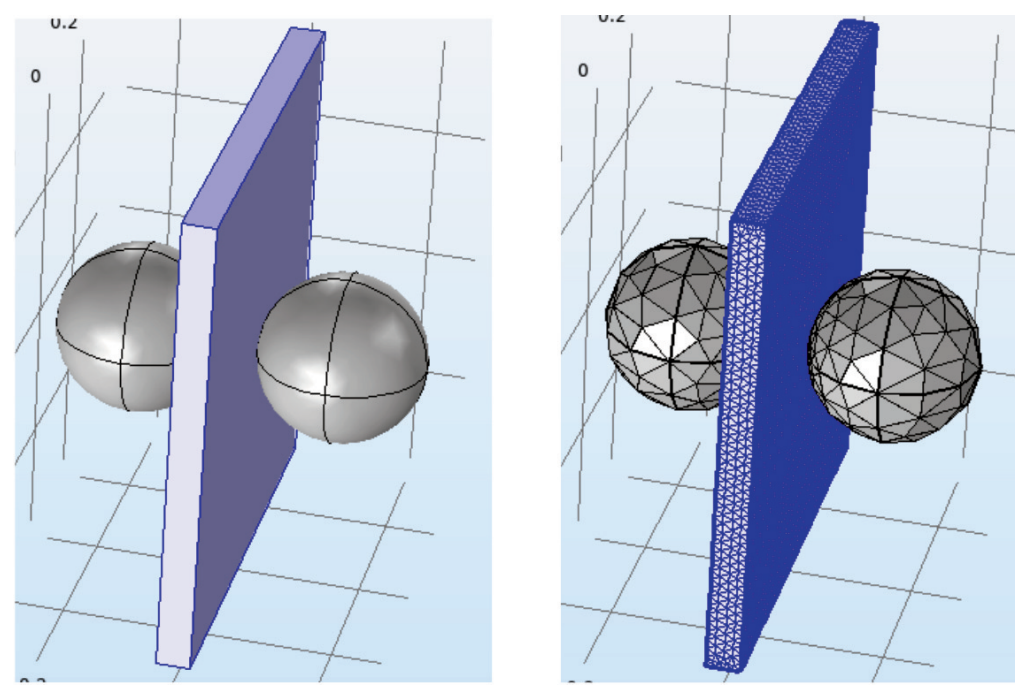

7. irudia. Lerro kritikoaren ingurutik dagoen sare oso fineko blokea.

Eremu elektrikoaren kalkulurako, haustura-tentsio bakoitzak distantziaz zatitu dira, (10) ekuazioan adierazi bezala. 


$$
E=\frac{V}{d}
$$

\subsubsection{Ionizazio-koefizientearen kalkulua}

Ionizazio-koefizientearen kalkulurako, Ver Planckek formulatutako funtzioa erabili da (1. irudia). Funtzio hori tarteka definituta dago, eremu elektrikoaren eta dentsitate-koefizientearen arabera. Kasu honetan, dentsitate-koefizientearen balioa unitarioa da, geometria baldintza normaletan ( $T=20{ }^{\circ} \mathrm{C}$ eta $\left.p=1 \mathrm{~atm}\right)$ aztertu delako. Ionizazio-koefizientea kalkulatzeko prozedura berdina da eremu elektriko uniformearentzat zein ez-uniformearentzat.

\subsection{3. $\mathrm{g}(\mathrm{x})$ kurben kalkulua}

Azken pausoa koroa-efektua agertuko den ala ez aztertzea da. Horretarako, aurretik lortutako bi $g(x)$ kurbak konparatu behar dira: bi $g(x)$ kurbek puntu batean elkar ukitzen badute, koroa-efektua agertuko da.

Horretarako, koordenatuak distantzia bihurtu behar dira (11) ekuazioaren bidez:

$$
d=\sqrt{x^{3}+y^{3}+z^{3}}
$$

Eremu elektriko ez-uniformearen eta uniformearen $g(x)$ funtzioak kalkulatzeko, (5) ekuazioa erabili behar da. Eremu elektriko ez-uniformean, $\alpha_{x}$ izango da jatorriko ionizazio-koefizientea, polaritatea positiboa izateagatik lerro kritikoaren hasieran dagoelako. Uniformean ionizazio-koefizientea konstantea dela kontuan izan behar da. Hortaz, integralaren balioa $\alpha$-ren eta distantziaren arteko biderketa izango da.

Aipatzekoa da koordenatu guztien distantzia $\alpha$ eta $g(x)$ kurben kalkulurako MATLAB softwarea erabili dela.

\subsection{Emaitzak}

\subsubsection{Eremu elektrikoaren kalkulua}

Simulazio-sarearen baldintzek eragin zuzena dute lerro kritikoaren eremu elektrikoan. Izan ere, nahiz eta geometria (kasu honetan esferak eta ingurunea) sare oso fin batez saretu, bestelako ingurua ez da hain fin saretzen. 8. eta 9. irudien arabera, simulatutako eremu elektrikoaren balioek balio esperimentalekin bat egiten dute. 
Ane Miren Larrea, Agurtzane Etxegarai, Manuel Antonio de la Hoz, Javier Mazón, Elvira Fernández.

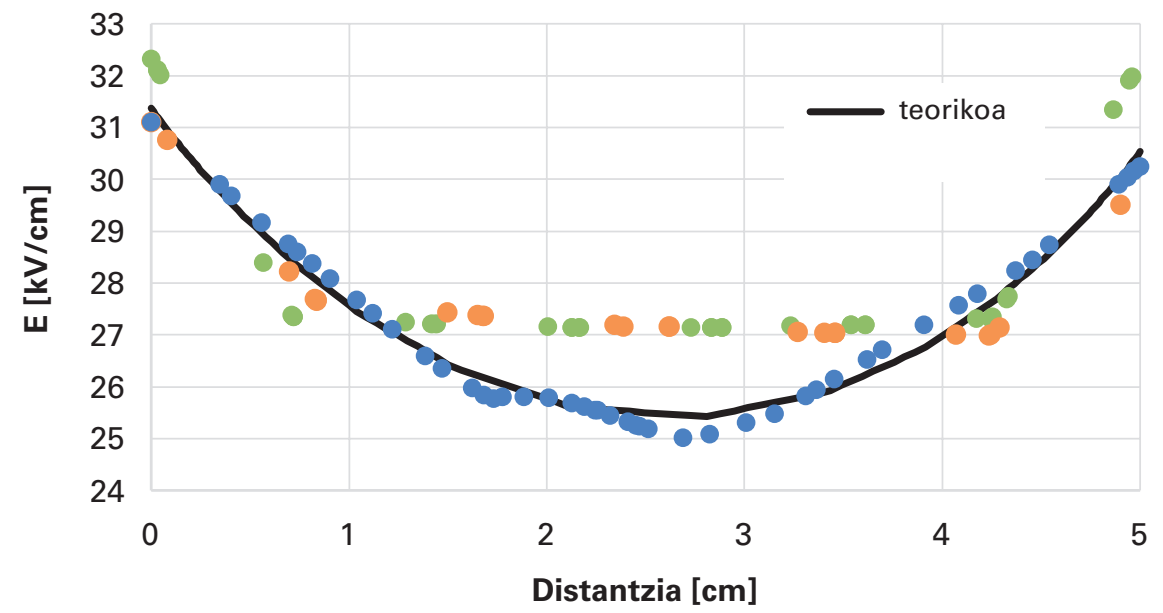

8. irudia. Bi esferen artean sortutako lerro kritikoaren eremu elektrikoa sare oso fineko blokea erabili gabe sare ezberdinetan.

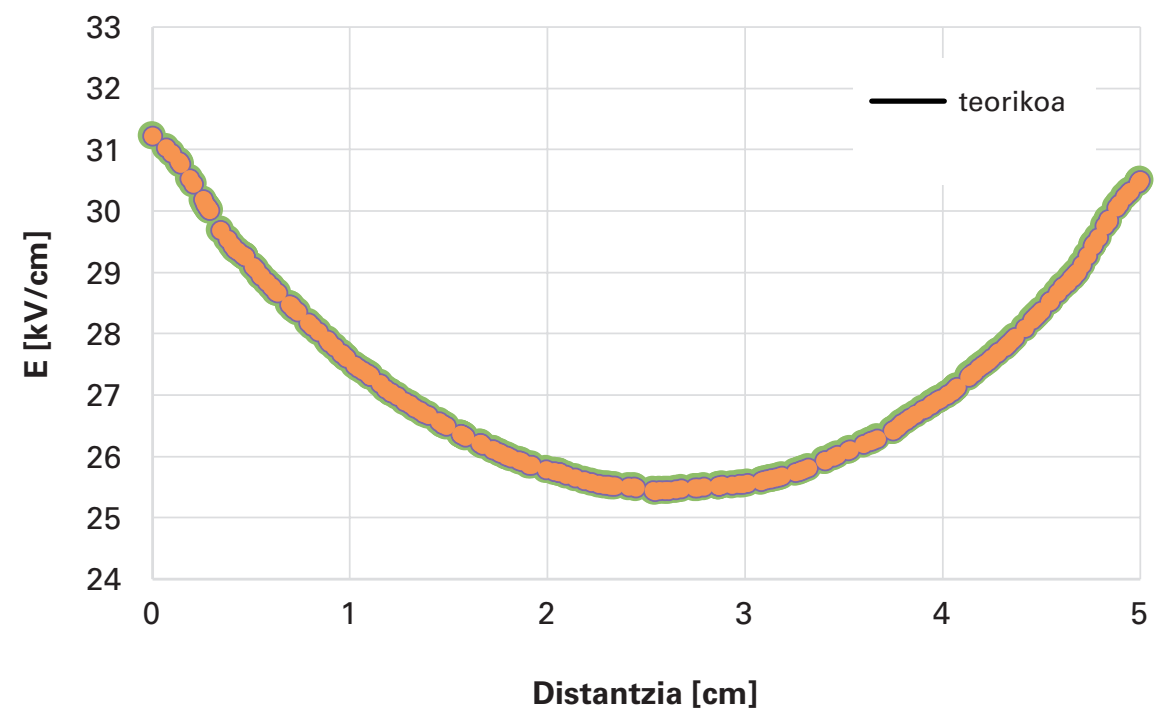

9. irudia. Bi esferen artean sortutako lerro kritikoaren eremu elektrikoa sare oso fineko blokea erabiliz sare ezberdinetan. 


\subsubsection{Ionizazio-koefizientearen kalkulua}

Artikulu honetan erabilitako metodologiaz lortutako emaitzek eta Jorgensen eta Pedersen-ek lortu zituzten emaitzek, 10. irudiaren arabera, bat egiten dute.
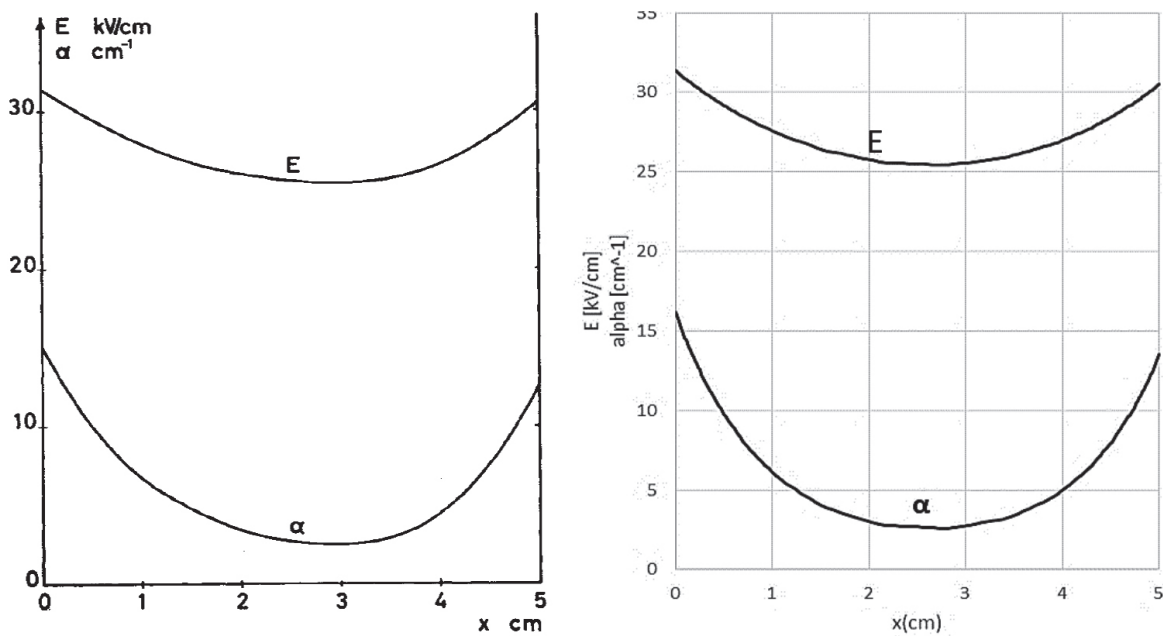

10. irudia. Lerro kritikoaren eremu elektrikoa eta ionizazio-koefizientea, teorikoki (ezkerrean) [7] eta proposatutako metodologiari jarraituz (eskuinean) [14].

\subsection{3. $\mathrm{g}(\mathrm{x})$ kurben kalkulua}

Egiaztatuta gelditzen da, 11. irudiaren arabera, $g(x)$ lortzeko metodologia.
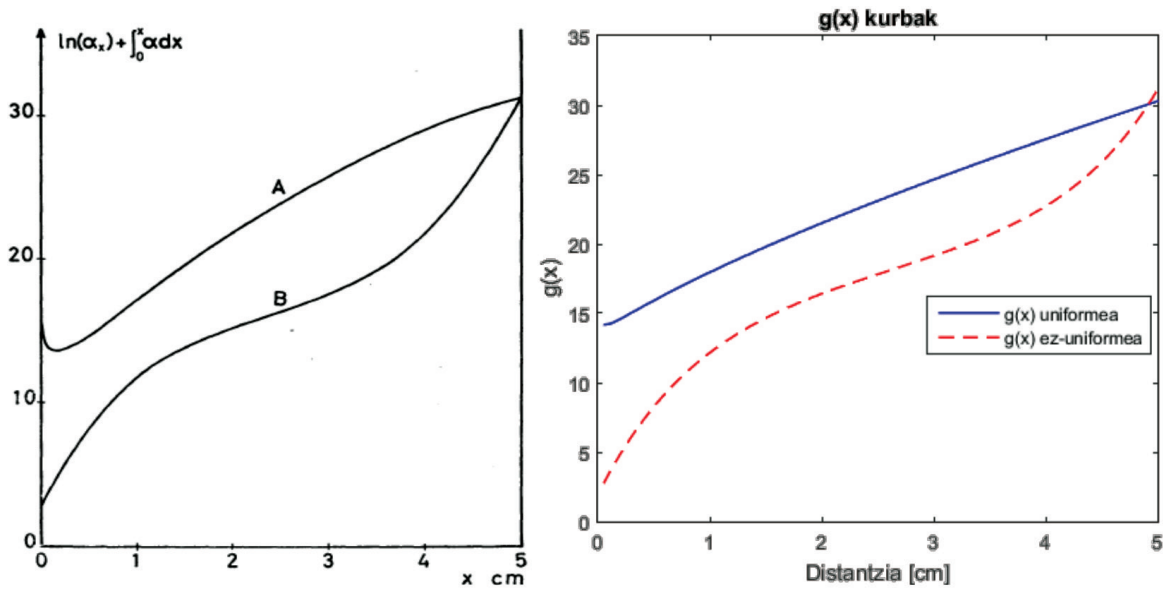

11. irudia. $g(x)$ kurbak teorikoki (ezkerrean) [7] eta proposatutako metodologiari jarraituz (eskuinean). 
Ane Miren Larrea, Agurtzane Etxegarai, Manuel Antonio de la Hoz,

Javier Mazón, Elvira Fernández.

\section{INGURUNEAREN, ELEKTRODOEN ETA SIMULAZIO-TRESNAREN ERAGINA KOROA-EFEKTUAREN AZTERKETAN}

Proposatutako metodologia egiaztatu ondoren, zenbait faktoreren eragina aztertu da koroa-efektuan: alde batetik, ingurune-baldintzak (tenperatura eta presioa); bestetik, elektrodoen geometria, eta, azkenik, simulazioingurunea.

\subsection{Metodologiaren deskribapena}

\subsubsection{Ingurune-baldintzak: tenperatura eta presioa}

Ingurumen-baldintzak aldatu ahal izateko, eremu elektriko uniformea eta ez-uniformea bereizi behar dira. Eremu elektriko uniformearen haustura-tentsioa kalkulatzeko baldintza normalak ez diren tenperaturan eta presioan, Paschenek baieztatu zuen dentsitate erlatiboak daukan potentziala zuzenki proportzionala dela $\delta$-rekiko eta baldintza estandarreko hausturatentsioarekiko (12) [9].

$$
V(\delta)=\delta \cdot V(\delta=1)
$$

Horrela, eremu elektriko uniformea baldintza berrietan kalkula daiteke.

$$
\begin{gathered}
E(\delta)=\frac{V(\delta)}{x}=\delta \cdot \frac{V(\delta=1)}{x}=\delta \cdot E(\delta=1) \\
E(\delta)=\delta \cdot E(\delta=1) \\
\frac{E(\delta)}{\delta}=\frac{\delta \cdot E(\delta=1)}{\delta}=E(\delta=1)
\end{gathered}
$$

Beraz, $\frac{E(\delta)}{\delta}=E(\delta=1)$ datua Ver Planck-en grafikoan sartuz (1. irudia), $\alpha / \delta$ lortzen da. Hortaz, ingurumen-baldintzak aldatzean, $\alpha$ dentsitate erlatiboaz biderkatu behar da.

Eremu elektriko ez-uniformea kalkulatzeko, 1. irudiaz baliatuz kalkula daiteke $\alpha$, eta, ondorioz, $g(x)$ ez-uniformea.

\subsubsection{Elektrodoen geometria: esfera-planoa}

Metodologiaren egiaztapena esfera-esfera geometriarako egin da soilik. Hala ere, metodologia edozein geometriatarako da baliagarria. Frogatzeko, 
esfera-esfera ez den geometria bat aztertu da: esfera-planoa. Plano batekin ordezkatu da tentsio nulura konektatuta dagoen esfera, betiere esferaren eta planoaren artean $5 \mathrm{~cm}$-ko distantzia mantenduz (12. irudia).

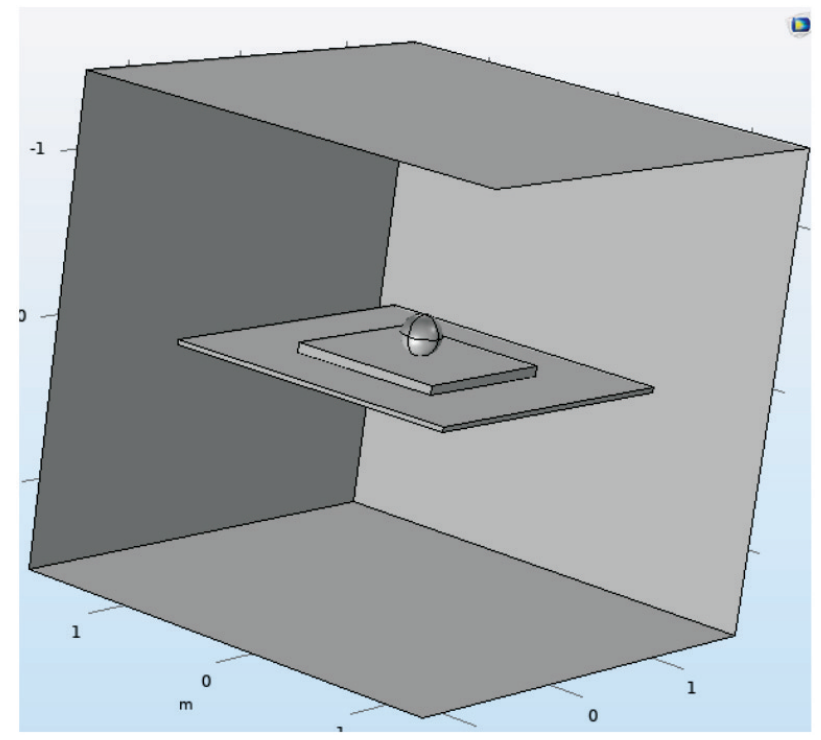

12. irudia. Esfera-plano geometria sare oso fineko blokearekin.

\subsubsection{Kurbadura}

Aurretik aztertu diren geometriak $25 \mathrm{~cm}$ diametroko esfera batean oinarrituta daude. Esferaren kurbadurak eremu elektrikoan eta, hortaz, koroa-efektuan duen eragina aztertzeko, hiru kurbadura ezberdinetako geometriak alderatuko dira $25 \mathrm{~cm}$-ko diametroko esfera-plano geometriarekin (1. taula).

1. taula. Elipseen neurriak.

\begin{tabular}{lccc}
\hline Geometria & $\mathrm{a}[\mathrm{cm}]$ & $\mathrm{b}[\mathrm{cm}]$ & $\mathrm{c}[\mathrm{cm}]$ \\
\hline Esfera & 12,5 & 12,5 & 12,5 \\
Elipsea (1) & 17,0 & 12,5 & 12,5 \\
Elipsea (2) & 25,0 & 12,5 & 12,5 \\
\hline
\end{tabular}


Ane Miren Larrea, Agurtzane Etxegarai, Manuel Antonio de la Hoz, Javier Mazón, Elvira Fernández.

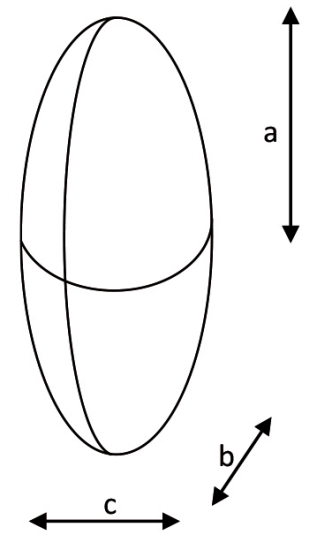

13. irudia. Elipsearen neurriak.

\subsubsection{Simulazio-ingurunearen dimentsioa}

Simulazio-inguruneak laborategiko dimentsioak simulatzen ditu. Errealitatera gehiago hurbiltzeko asmoz, esferari kable batzuen bidez eutsi zaio. Euskarria zilindro bertikal batez eta eroale horizontal batez osatuta dago. Eroalearen muturrak isolatzeko, pantailatze-esfera bana jarri da muturretan.

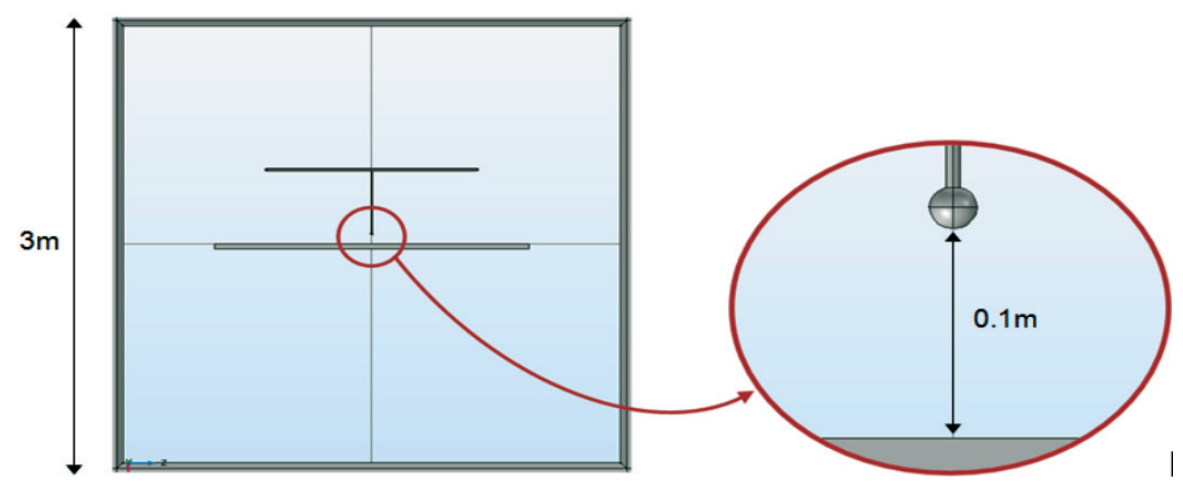

14. irudia. Esfera-plano geometria $3 \times 3 \times 3$ m-ko ingurunean.

Aztertu diren geometria guztiak bi elektrodoz osatuta daude, haien arteko distantzia txikia izanik ingurunearekiko dimentsioekin alderatuz (14. irudia). Ondorioz, ingurunearen dimentsioak ez du eraginik lerro kritikoaren eremu elektrikoan. $g(x)$ kurbak kalkulatzeko orduan desbiderapen txiki bat ikus daiteke (16. irudia). Errore hori, hala ere, simulazio bakoitzean sarea apur bat aldatzen delako agertzen da, eremu elektrikoan ezber- 
dintasun txiki bat eragiten baita. Eremu elektrikoa eta $g(x)$ kurbak, beraz, inguruneko dimentsio ezberdinetarako geometriaren planoa kenduta kalkulatuko dira, betiere esfera erdian mantenduz. Probak $20 \mathrm{~mm}$ diametroko esfera batean egin dira.

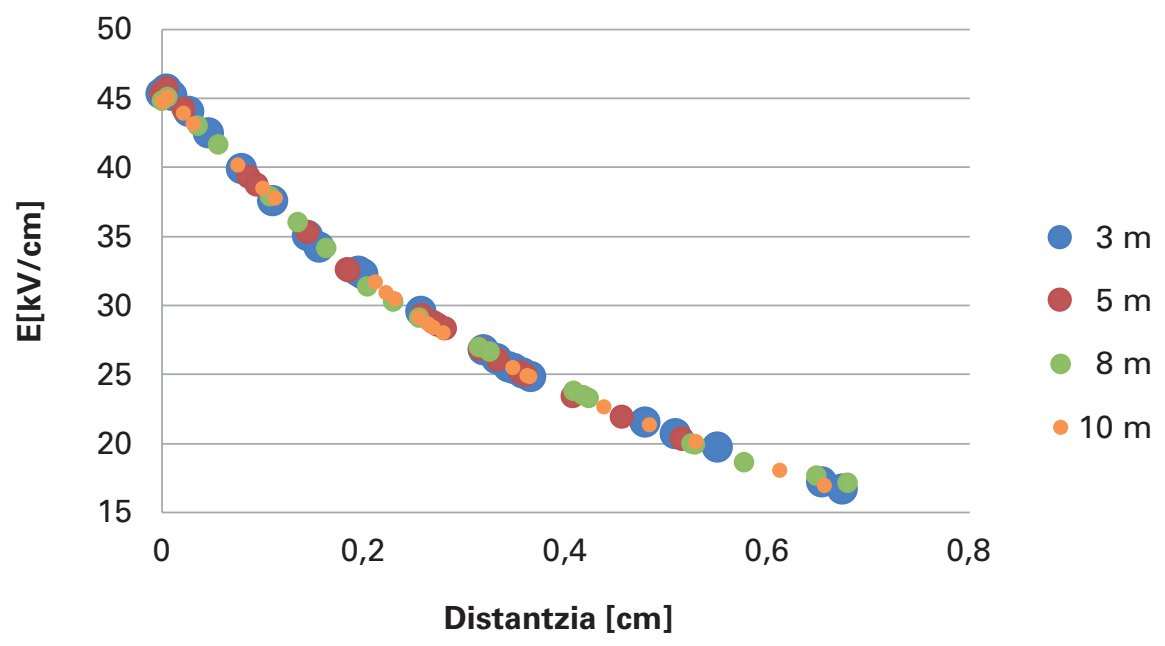

15. irudia. Esfera-plano geometriaren streamlineko eremu elektrikoa 3, 5, 8 eta $10 \mathrm{~m}$-ko inguruneetan.

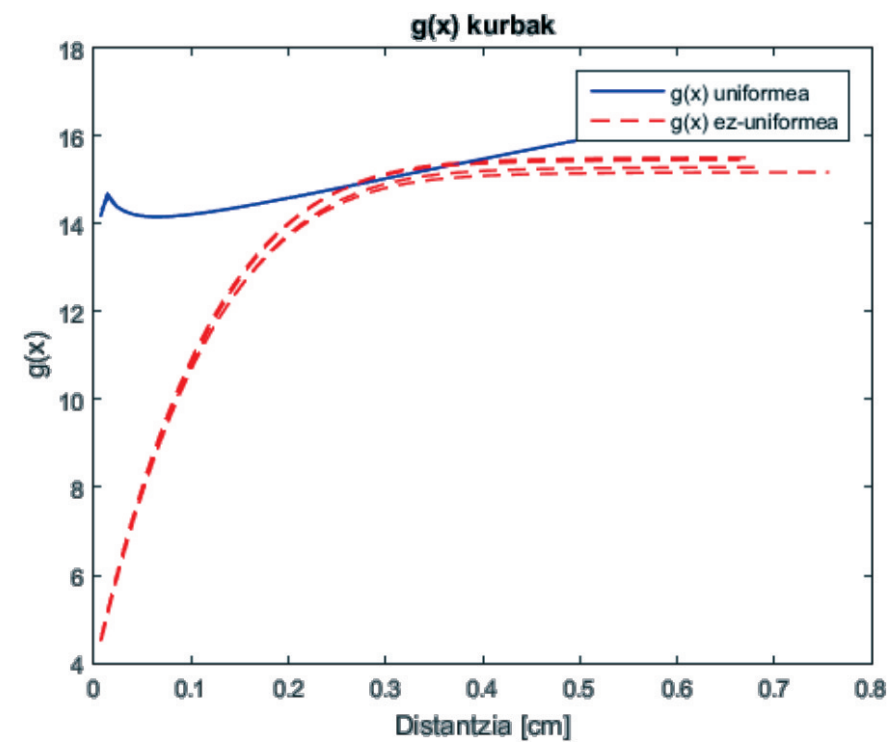

16. irudia. Esfera-plano geometriaren $g(x)$ kurbak 3, 5, 8 eta $10 \mathrm{~m}$-ko inguruneetan. 
Ane Miren Larrea, Agurtzane Etxegarai, Manuel Antonio de la Hoz, Javier Mazón, Elvira Fernández.

\subsection{Emaitzak}

\subsubsection{Ingurune-baldintzak: tenperatura eta presioa}

Tenperatura eta presioa kontuan izateko, dentsitate erlatiboa kalkulatzea ezinbestekoa da. Tenperaturaren eragina 17. irudian ikus daiteke, presioa konstante mantentzen delarik (1 atm). Eremu elektriko uniformeko $g(x)$ kurbetan, tenperaturak ez du eragin handirik, baina ez-uniformean, aldiz, haren eragina oso nabaria da. Tenperatura gora doan heinean, $g(x)$ ezuniformeak ere gora egiten du, bi kurbak puntu batean elkartzeko probabilitatea handituz.

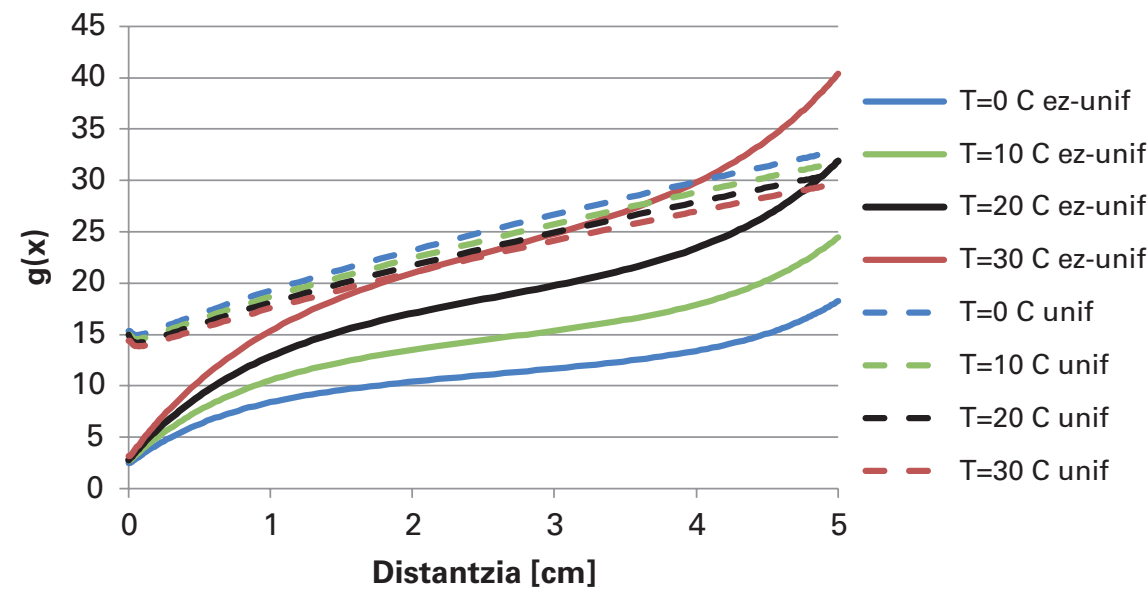

17. irudia. $g(x)$ kurbak tenperatura ezberdinetan, presioa $1 \mathrm{~atm}$ eta $V=136 \mathrm{kV}$ direnean.

Presioak, bestalde, $g(x)$ uniformean ez du eragin handirik, baina ezuniformean, aldiz, handia da haren eragina (18. eta 19. irudiak). Zenbat eta presioa handiago izan, hainbat eta txikiago da $g(x)$ kurbak elkartzeko probabilitatea. Gainera, zenbat eta presioa txikiago izan, orduan eta hurbilago agertuko da koroa-efektua tentsiopean dagoen esferatik. 


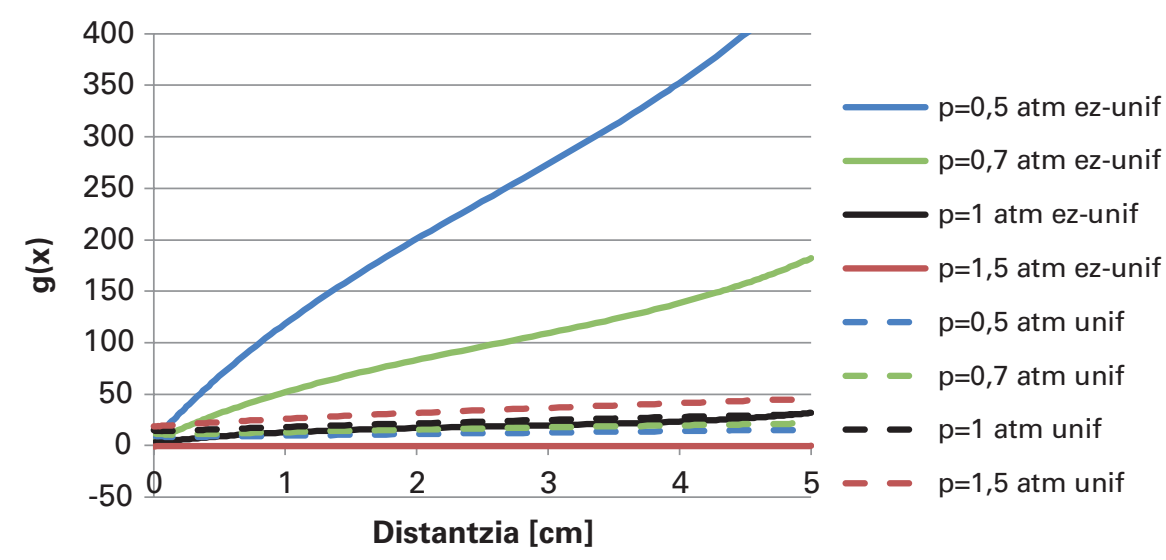

18. irudia. $g(x)$ kurbak presio ezberdinetan, tenperatura $20^{\circ} \mathrm{C}$ eta $V=136 \mathrm{kV}$ direnean.

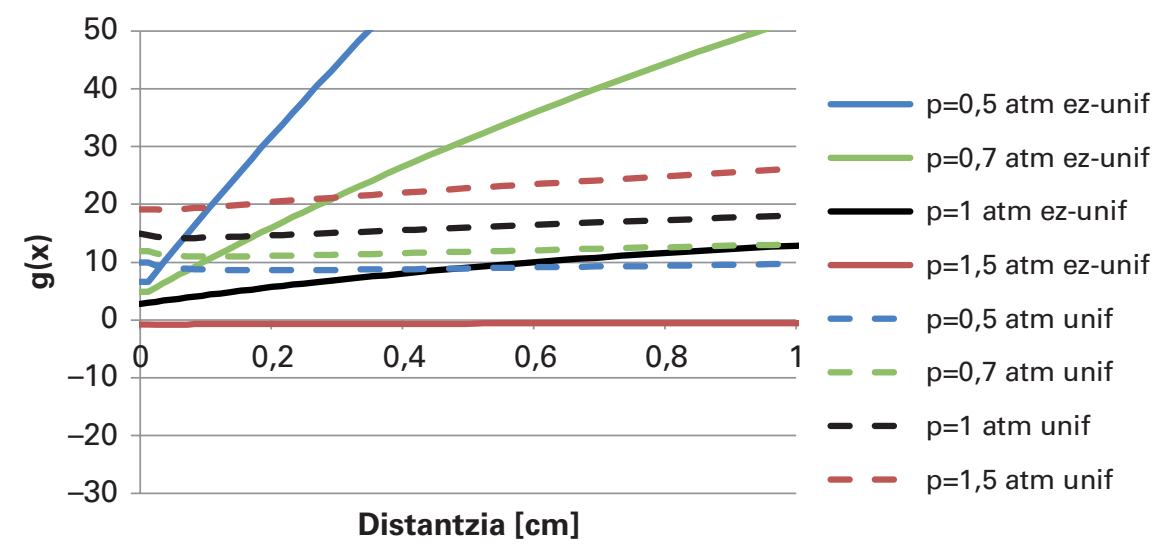

19. irudia. $g(x)$ kurbak presio ezberdinetan, tenperatura $20{ }^{\circ} \mathrm{C}$ eta $V=136 \mathrm{kV}$ direnean.

Laburbiltzeko, tenperatura zenbat eta handiago izan, gero eta gorago egongo da eremu ez-uniformearen $g(x)$ funtzioa; handiagoa da eremu uniformearen $g(x)$ funtzioarekin elkartzeko probabilitatea. Presioarekin kontrakoa gertatzen da, koroa-efektua agertzeko probabilitatea handitzen baita presioa txikitzean. 
Ane Miren Larrea, Agurtzane Etxegarai, Manuel Antonio de la Hoz, Javier Mazón, Elvira Fernández.

\subsubsection{Elektrodoen geometria: esfera-planoa}

Elektrodoen geometriak koroa-efektuan duen eragina 20. irudian ikus daiteke. Hau da, eremu elektrikoa guztiz aldatzen da geometria ezberdinetarako, balioan zein itxuran. Hortaz, frogatuta dago geometria aldatzen den bakoitzean metodologia osoa errepikatu behar dela. Izan ere, eremu elektrikoa birsimulatu beharko da EFM bitartez.

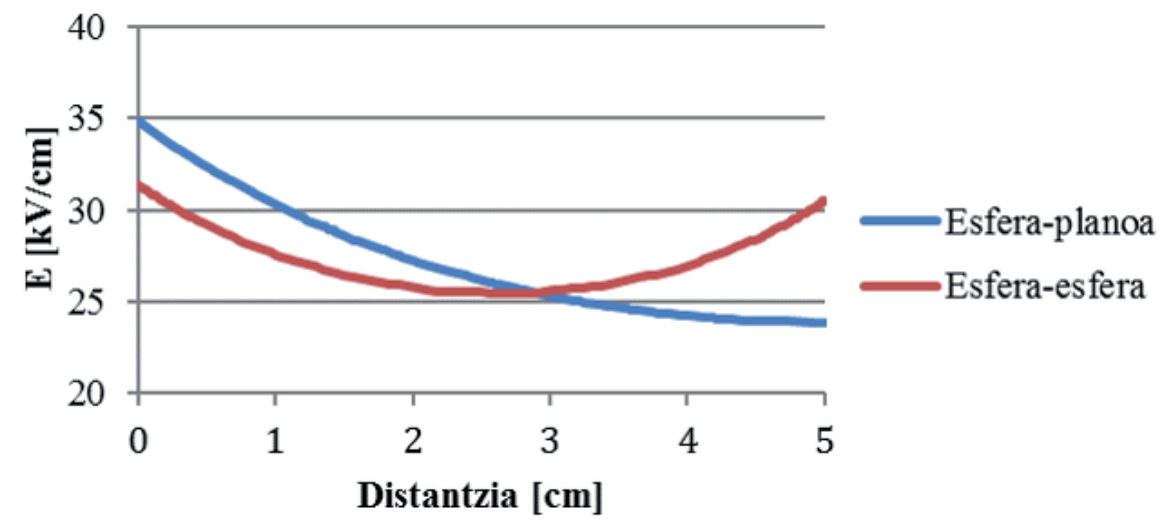

20. irudia. Eremu elektrikoa lerro kritikoan esfera-plano eta esfera-esfera geometrietan.

\subsubsection{Kurbadura}

Elipsearen kasuan, eremu elektrikoa ez da bat-batean aldatzen, baizik eta gradualki handitzen da elipsearen puntarantz (21. irudia), hau da, eremu elektriko maximoko punturantz.

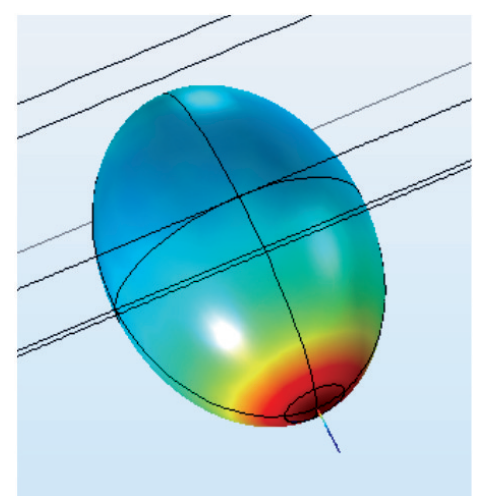

21. irudia. 2. elipsearen eremu elektrikoa eta lerro kritikoa. 


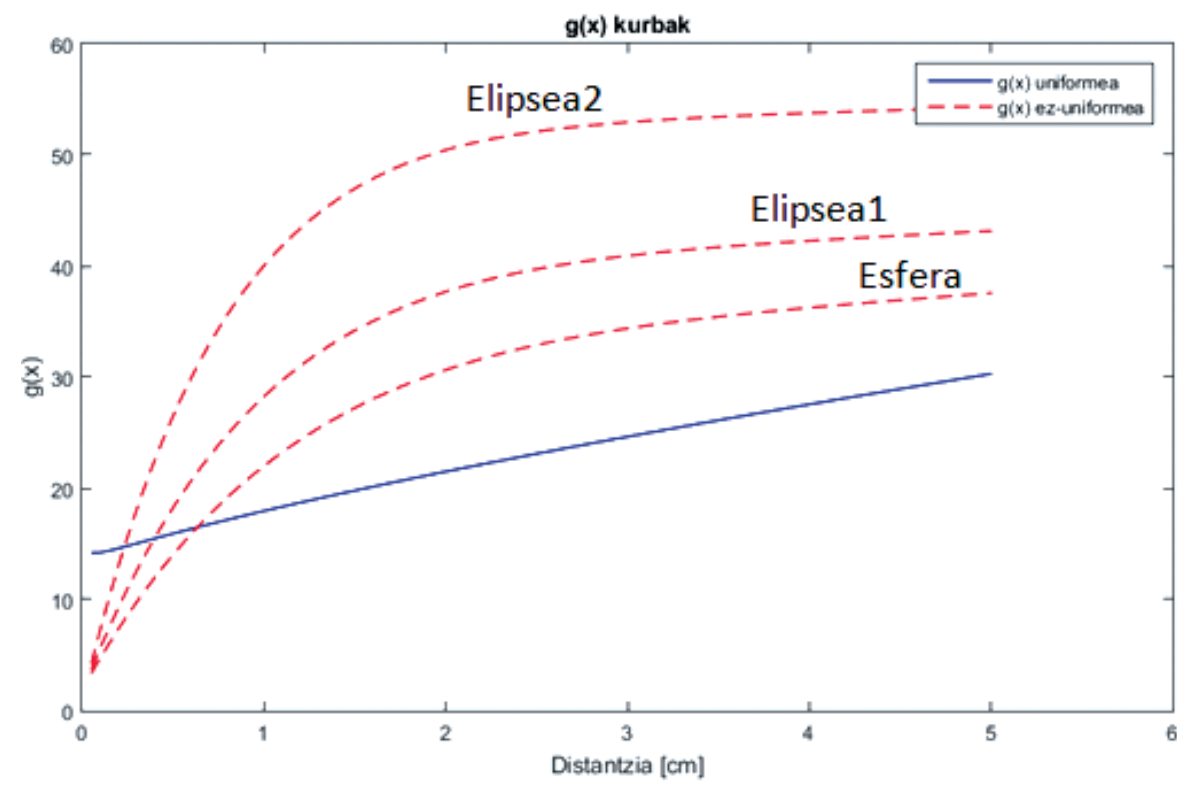

22. irudia. $g(x)$ kurbak esfera-plano geometrian kurbatura ezberdinetan, $V=136 \mathrm{kV}$ izanik.

Kurbadura zenbat eta zorrotzagoa izan (hau da, elipsea zenbat eta gehiago luzatu), gero eta gorago egongo da $g(x)$ ez-uniformeko kurba. Hortaz, piezak daukan kurbaduraren arabera eremu elektrikoa aldatuko da. Hortaz, pantailatze-esferen beharra frogatzen da. Kableen muturrak sekzio zorrotzekoak izango balira, muturretan eremu elektriko maximoko puntua agertuko litzateke. Ondorioz, koroa-efektua hor agertuko litzateke. Pantailatze-esferak bitarteko, konpondu egiten da arazo hori. Beraz, aztertutako geometriaren kurbadura zenbat eta txikiagoa izan, hainbat eta handiagoa da koroa-efektua agertzeko probabilitatea.

\subsubsection{Simulazio-ingurunearen dimentsioa}

23. irudian ikus daitekeenez, eremu elektrikoa ingurunearen dimentsioarekin aldatzen da. Aldaketa hau kuantifikatzeko asmoz, eremu elektriko maximoko puntuak konparatu dira inguruneko hainbat dimentsiotarako (24. irudia). 
Ane Miren Larrea, Agurtzane Etxegarai, Manuel Antonio de la Hoz, Javier Mazón, Elvira Fernández.

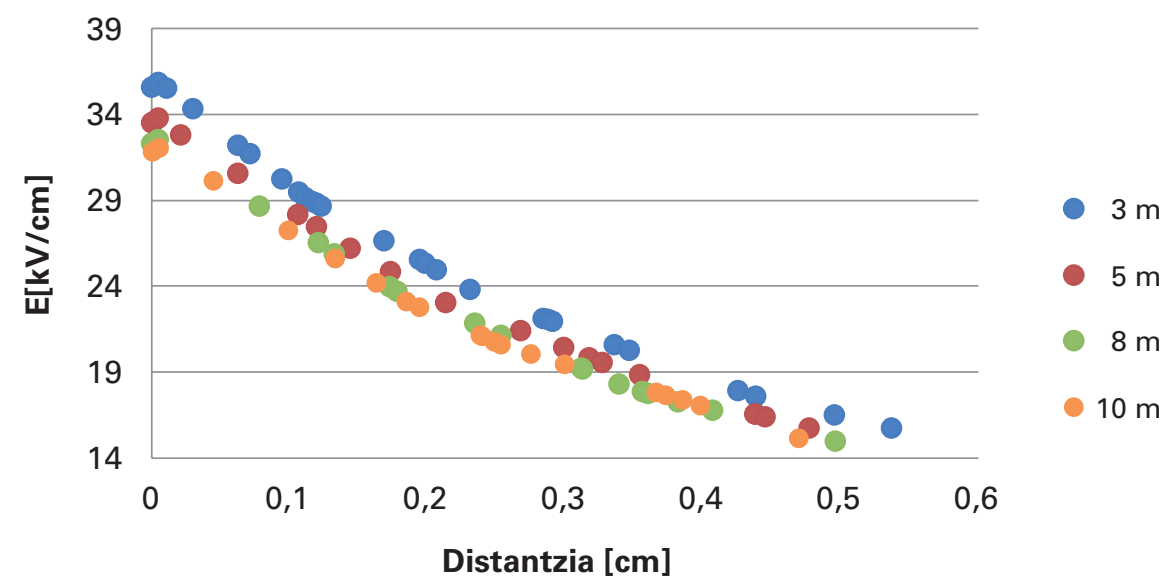

23. irudia. Lerro kritikoko eremu elektrikoa, 3, 5, 8 eta 10 m-ko simulazio-inguruneetan.

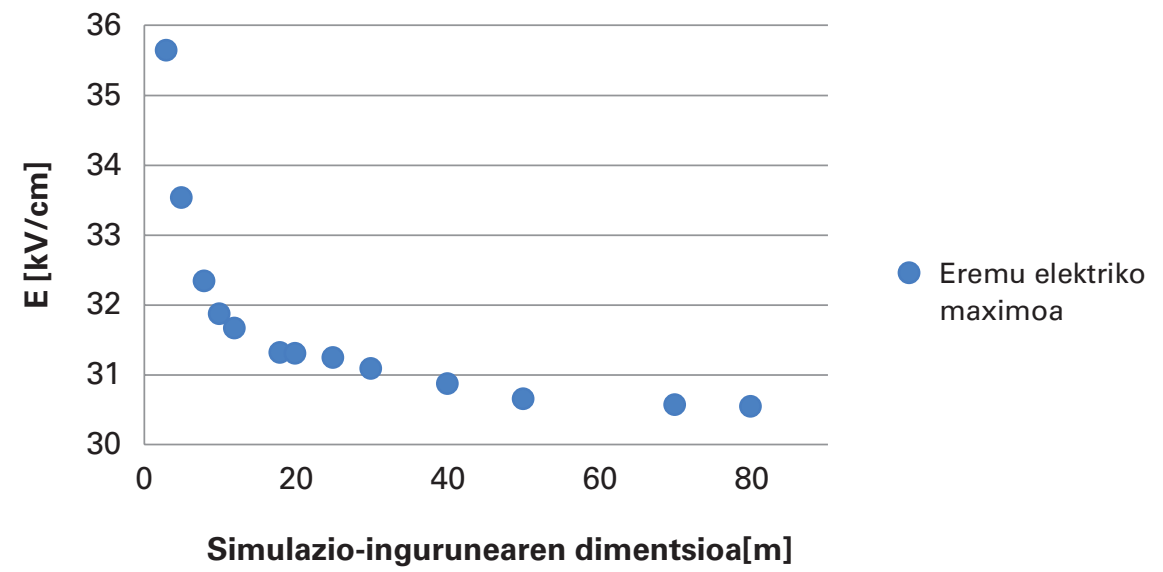

24. irudia. Puntu maximoko eremu elektrikoa inguruneko hainbat dimentsiotarako.

Ingurunearen dimentsioak eragin handia du eremu elektrikoan elektrodo bakarra dagoenean, esfera kasu honetan. Horrenbestez, ingurunearen dimentsioak zehaztea ezinbesteko pausoa da. Lortutako emaitzak emaitza esperimentalekin konparatu nahi badira, ingurunearen dimentsioak laborategikoen berdinak izan behar dira. Hala, errealitatean koroaefektua pairatuko duten piezak aire zabalean egongo dira, eta aire zabaleko dimentsioak simulatzea zailagoa izango da. Dena den, ikus daiteke 
nola kasu honetan 40 m-tik gora lortutako emaitzak nahiko antzekoak diren. Beraz, eremu elektrikoak bat egiten du inguruneko dimentsioarekin. Hortaz, inguruneko dimentsio kritiko batetik aurrera aire zabala simulatzen da. 40 m-ko muga aztertutako geometriarentzat baino ez da baliagarria. Beste geometria batzuentzat (tamainaz zein itxuraz), berriz, frogatu egin beharko litzateke.

\section{ONDORIOAK}

Koroa-efektuaren ondorioz, hainbat galera sortzen dira goi-tentsioko linea elektrikoetan, eta, ondorioz, efizientzia murrizten da. Gainera, isolamenduan eta gailu batzuetan kalteak eragin ditzake. Beraz, koroa-efektuaren ezagutza eta ikerketa beharrezkoak dira tentsio altuko gailuak diseinatzeko orduan. Hala, diseinuaren prozesua optimizatze aldera, gaur egun simulazio-ereduak erabiltzen dira. Honako artikulu honek, hain zuzen ere, elementu finituen simulazio-tresna baten bidez aztertu du goi-tentsioko lineetan sortzen den koroa-efektua. Izan ere, lerro kritikoaren eremu elektrikoaren kalkulurako, elementu finituen metodoa erabili da, COMSOL multiphysics softwarearen bitartez.

Koroa-efektua maila mikroskopikoan eta makroskopikoan aztertu da lan honetan, eta, aztertutako literaturan oinarrituta, haren detekziorako metodologia bat proposatu da. Metodologia hori egiaztatu ondoren, hainbat faktorek (hala nola ingurune-baldintzak, geometriak eta simulazio-inguruneak) koroa-efektuan duten eragina ikertu da.

Izan ere, eremu elektrikoa geometriaren eta inguruneko baldintzen (tenperatura eta presioa) mende dago. Geometria bakoitzarentzat eremu elektrikoa guztiz aldatzen da. Gainera, geometriaren kurbadura zenbat eta zorrotzagoa izan, hainbat eta handiago izango da eremu elektronikoa; ondorioz, koroa-efektua agertzeko probabilitatea ere handitzen da. Airearen tenperaturak eta presioak ere eragin zuzena dute. Aldagai hauek kontuan izateko, ezinbestekoa izango da dentsitate erlatiboaren erabilera, ionizazio-koefizientearekin proportzionalki erlazionatuta baitago. Zenbat eta tenperatura handiago izan edo zenbat eta presioa txikiago izan, hainbat eta handiagoa izaten da koroa-efektua agertzeko probabilitatea.

Simulazio-ingurunearen dimentsioak kontuan izan behar dira. Izan ere, ingurunearen paretak lurrera konektatuta daudenez, eremu elektrikoaren balioak aldatuko dira neurrien arabera. Simulazio-ingurunea handia izanik aztertutako piezarekin konparatuz, aire zabalean simulatzea lor daiteke. Dena den, simulazio-inguruneak ez du inolako eraginik izango baldin, pieza bakarra simulatu ordez, elkarrengandik hurbil dauden bi elektrodo simulatzen badira. 
Ane Miren Larrea, Agurtzane Etxegarai, Manuel Antonio de la Hoz, Javier Mazón, Elvira Fernández.

Laburbilduz, lan honetan aztertutako faktoreek eragin zuzena dute lerro kritikoko eremu elektrikoan eta, ondorioz, koroa-efektuaren agerpenean. Beraz, koroa-efektua detektatzea ez da begi hutsez egin daitekeen eragiketa; hainbat xehetasun kontuan izan behar dira. Hortaz, pieza zehatz baterako, ingurune-baldintzak, piezak dituen kurbadurak eta ingurunearen dimentsioak kontuan izatea ezinbestekoa izango da.

\section{BIBLIOGRAFIA}

[1] Ravindra Arora eta Wolfgang Mosch. 2011. High Voltage and Electrical Insulation Engineering. Wiley-IEEE Press.

[2] M. Goldman eta R. S. Sigmond. 1981. «Corona and insulation». Conference on Electrical Insulation Dielectric Phenomena - Annual Report 1981, 214215.

[3] C. L. Wadhwa. 2007. High Voltage Engineering. New Age International.

[4] S. J. Townsend eta J. S. E. Townsend. 1915. Electricity in Gases. Clarendon Press.

[5] L. B. Loeb. 1929. «The Mechanism of Spark Discharge in Air at Atmospheric Pressure». Science, 69, 509-512.

[6] F. W. Peek. 1911. "The law of corona and the dielectric strength of air». Proceedings of the American Institute of Electrical Engineers., 30, 14851561.

[7] A. Pedersen. 1967. «Calculation of Spark Breakdown or Corona Starting Voltages in Nonuniform Fields». IEEE Transactions on Power Apparatus and Systems, PAS-86, 200-206.

[8] D. W. V. Planck. 1941. «Calculation of Initial Breakdown Voltages in Air». Transactions of American Institute of Electrical Engineers, 60, 99-104.

[9] E. Kuffel, W. S. Zaengl, eta J. Kuffel. 2000. High Voltage Engineering Fundamentals. Elsevier.

[10] A. N. Kontaratos. 1965. «On the functional dependence of Townsend's first ionization coefficient». Appied Scientific Research, 12, 27-32.

[11] T. W. Dakin. 1974. «Breakdown of Gases in Uniform Fields-Paschen Curves for Nitrogen, Air and Sulfur Hexafluoride». Electra, 32, 61-82.

[12] P. Haefliger eta C. M. Franck. 2018. «Detailed precision and accuracy analysis of swarm parameters from a pulsed Townsend experiment». Review of Scientific Instruments, 89, 023114.

[13] Voltinum España. 2017. «Efecto corona en líneas de transmisión y transformadores». [Online]. Available at: https://www.voltimum.es/articulos-tecnicos/efecto-corona-lineas.

[14] Ane Miren Larrea. 2018. «Aireko lineetako koroa-efektuaren analisia elementu finituen bidezko simulazioaz». Euskal Herriko Unibertsitatea UPV/ EHU. 